\title{
Chemically-Induced Uptake of Gold by Root Crops: Its Significance for Phytomining
}

\author{
Fletcher A Msuya, Robert R Brooks and Christopher WN Anderson \\ Soil and Earth Sciences, Institute of Natural Resources, Massey University, Palmerston North, New Zealand \\ E-mail: R.Brooks@massey.ac.nz
}

\section{Received: 29 December 1999}

Five root crops (carrot, red beet, onion and two cultivars of radish) were grown in an artificial substrate consisting of $3.8 \mathrm{mg} / \mathrm{kg}(\mathrm{ppm})$ of elemental gold dispersed in sand. The possibility of using these crops for phytomining for gold was determined by separately adding the chelating agents ammonium thiocyanate and ammonium thiosulfate at respective rates of 1 and $2 \mathrm{~g} / \mathrm{kg}$ to the substrate after a growing period of 9 weeks. The plants were harvested 10 days later and analysed for gold by atomic absorption spectrometry. In most cases, gold concentrations were higher in the roots than in the above-ground plant material. The highest mean gold concentrations were found in carrot roots $(48.3 \mathrm{mg} / \mathrm{kg}$ dry weight), and roots of two radish cultivars (113 and $102 \mathrm{mg} / \mathrm{kg}$ dry weight). Because of the very high biomass yield of carrot $(16 \mathrm{t} / \mathrm{ha}$ - dry weight), this plant showed the best potential for phytomining for gold. After allowing for reduced biomass yields over mine tailings, and taking into account the cost of the chelates as well as agrarian expenses and the cost of burning the crop, it was concluded that there was some potential of use of carrot to grow an economic crop of gold from mine tailings. None of the other four plants had potential for this purpose.

Thiocyanate-induced gold uptake by plants was first reported by Anderson et al (1) in 1998 and later reviewed (2). These authors induced gold uptake of up to $57 \mathrm{mg} / \mathrm{kg}$ ( $\mathrm{ppm})$ in dried leaves of Brassica juncea (Indian mustard) and proposed that it might be possible to use these, or other plants, to carry out phytomining for gold by growing crops over mine tailings or other suitable substrates.

In the course of later experiments, we have observed that gold concentrations in plants tended to be higher in the roots than the above-ground shoots when thiocyanate-induced gold uptake was initiated. We therefore carried out further experiments on accumulation of gold using harvestable root crops including radish, beet, onion, and carrot. We used both thiocyanate and thiosulfate as inducing agents in these experiments which are reported below.

\section{MATERIALS AND METHODS}

\section{Plants}

The following plants were selected for the experiments: Raphanus sativus 'oriental radish' and 'salad radish',
Beta vulgaris 'Derwent globe', Allium cepa 'Pukekohe longkeeper', and Daucus carota 'Topweight carrot'. The seeds were initially sown in standard commercial seed-raising compost and then transplanted into the auriferous substrate after the first pair of true leaves had appeared.

\section{Auriferous Substrate}

Plants were grown in fine $(<0.5 \mathrm{~mm})$ silica sand $(\mathrm{pH}$ 6.4) containing $3.8 \mathrm{mg} / \mathrm{kg}(\mathrm{ppm})$ finely divided gold prepared by adding gold chloride to the sand and then heating to $>100^{\circ} \mathrm{C}$ to convert the gold to the elemental state. 'Osmocote' slow release (4-5 months) fertiliser was then added to the substrate at the rates recommended by the manufacturer.

\section{Plant Growth Experiments}

Plants in varying replicates for each of three treatments (controls, thiocyanate, and thiosulfate), were grown for 9 weeks in $250 \mathrm{~mL}$ or $500 \mathrm{~mL}$ plastic pots (depending on anticipated root size of the plant) in a greenhouse maintained at $20-25^{\circ} \mathrm{C}$ and with random changing of pot positions to ensure consistency of illumination. At the end of the 
growing period, $1 \% \mathrm{w} / \mathrm{v}$ solutions of ammonium thiocyanate or $2 \% \mathrm{w} / \mathrm{v}$ ammonium thiosulfate were applied to the substrates at rates of $1.0 \mathrm{~g} / \mathrm{kg}$ of thiocyanate and $2.0 \mathrm{~g} / \mathrm{kg}$ of thiosulfate respectively. After a period of 10 days, the thiocyanate-treated plants had died though those treated with thiosulfate still had viability. The plant material was then harvested and dried at $70^{\circ} \mathrm{C}$.

\section{Chemical Analysis}

Dried plant samples $(c a 0.5 \mathrm{~g})$ were ignited at $500^{\circ} \mathrm{C}$ in borosilicate test tubes and the ash heated over a hot plate with $5 \mathrm{~mL}$ of aqua regia until the volume had been reduced to about $1 \mathrm{~mL}$. The residues were then diluted to $10 \mathrm{~mL}$ with deionised water and analysed for gold using a GBC 909 atomic absorption spectrometer capable of determining down to 0.5 $\mathrm{mg} / \mathrm{L} \mathrm{(ppm)} \mathrm{gold} \mathrm{in} \mathrm{the} \mathrm{solution.} \mathrm{For} \mathrm{gold}$ concentrations lower than $0.5 \mathrm{mg} / \mathrm{L}, 4 \mathrm{~mL}$ aliquots of the aqueous solution were shaken with $2 \mathrm{~mL}$ of methylisobutylketone (MIBK) and the organic layer analysed for gold by graphite furnace atomic absorption spectrometry (GFAAS) using a GBC System 3000 instrument with a limit of detection of about $5 \mu \mathrm{g} / \mathrm{L}$ (ppb).

\section{RESULTS AND DISCUSSION}

Concentrations of gold in above-ground parts and roots of the five vegetables surveyed, are given in Table 1. Values in some cases exceeded $200 \mathrm{mg} / \mathrm{kg}$ and were much higher than the maximum of $57 \mathrm{mg} / \mathrm{kg}$ reported for Brassica juncea (1). Concentrations were in most cases higher in roots than in aerial plant parts.

The controls showed no measurable uptake of gold (ie $<5 \mu \mathrm{g} / \mathrm{kg}[\mathrm{ppb}]$ ) thus confirming the presence of gold in the substrate in an immobile form before chemical treatment. In terms of the mean gold concentrations of plants treated with thiocyanate, roots of nearly all species contained significantly more gold than the tops and in descending order can be ranked as: salad radish $>$ oriental radish $>$ carrot $>$ onion $>$ red beet.

Thiosulfate addition produced results comparable with those obtained with thiocyanate. In descending order the gold values in roots were: carrots $>$ red beet $>$ onions.

The final column of Table 1 shows the expected gold yield in $\mathrm{g} / \mathrm{ha}$ for a root crop assuming that yields would be the same as for a commercial crop grown under optimum conditions. Such ideal conditions are

Table 1 Gold Concentrations ( $m g / k g d r y$ weight) in Root Crops Grown in a Substrate with $3.8 \mathrm{mg} / \mathrm{kg}$ gold

\begin{tabular}{|c|c|c|c|c|c|c|c|}
\hline $\begin{array}{l}\text { Plant or } \\
\text { treatment }\end{array}$ & $\begin{array}{c}\text { Yield } \\
\text { (t/ha)* }\end{array}$ & $\mathbf{N}$ & Mean & $\begin{array}{l}\text { Std. } \\
\text { dev. }\end{array}$ & $\begin{array}{c}\text { Highest } \\
\text { Au }\end{array}$ & $\begin{array}{c}\% \text { of } \\
\text { total Au }\end{array}$ & $\begin{array}{l}\text { Gold yield } \\
(\mathrm{g} / \mathrm{ha})^{* *}\end{array}$ \\
\hline \multicolumn{8}{|l|}{ THIOCYANATE } \\
\hline Carrot tops & 2 & 2 & 3.16 & 0.06 & 3.21 & 19 & 6 \\
\hline Carrot roots & 16 & 2 & 48.3 & 46.6 & 81.2 & 81 & 773 (779) \\
\hline Onion tops & 2 & 3 & 12.0 & 11.6 & 27.2 & 41 & 24 \\
\hline Onion roots & 10 & 3 & 13.8 & 10.9 & 24.6 & 59 & $138(162)$ \\
\hline Red beet tops & 3 & 4 & 6.50 & 2.10 & 10.3 & 35 & 20 \\
\hline Red beet roots & 11 & 4 & 5.00 & 3.70 & 9.05 & 65 & $55(75)$ \\
\hline Salad radish tops & 1 & 15 & 10.6 & 10.2 & 28.3 & 12 & II \\
\hline Salad radish roots & 2 & 15 & 113 & 27.4 & 220 & 88 & $226(237)$ \\
\hline Oriental radish tops & 1 & 9 & 5.00 & 4.90 & 14.3 & 7 & 5 \\
\hline Oriental radish roots & 2 & 9 & 102 & 100 & 162 & 93 & 204 (209) \\
\hline \multicolumn{8}{|l|}{ THIOSULFATE } \\
\hline Carrot tops & 2 & 4 & 12.9 & 3.00 & 15.9 & 31 & 26 \\
\hline Carrot roots & 16 & 4 & 89.0 & 74.0 & 189 & 69 & $1424(1450)$ \\
\hline Onion tops & 2 & 3 & 21.5 & 13.4 & 35.8 & 76 & 43 \\
\hline Onion roots & 10 & 3 & 2.60 & 2.10 & 4.30 & 24 & $26(69)$ \\
\hline Red beet tops & 3 & 6 & 4.10 & 1.30 & 5.04 & 71 & 12 \\
\hline Red beet roots & II & 6 & 3.20 & 1.00 & 4.72 & 29 & $35(47)$ \\
\hline
\end{tabular}

* Source: Clarke et al (3) and based on wet weight.

** Values in parentheses are the totals of tops and roots. 
not likely to be achieved under practical conditions in the field, especially over sterile mine tailings, possibly of low pH. Nevertheless, this expected yield has been retained in calculations of the anticipated economics of the system, because the allowance for costs of the chemicals was based on our use of $1 \mathrm{~g} / \mathrm{kg}$ for thiocyanate and $2 \mathrm{~g} / \mathrm{kg}$ for thiosulfate. It has been shown (1) that optimum gold yields could be obtained with a loading of $0.4 \mathrm{~g} / \mathrm{kg}$ when using thiocyanate. Our allowance of \$US6950/ha for agronomic, incineration, and chemical costs is based on the following calculation:

Growing and harvesting a hectare of land providing $18 \mathrm{t} / \mathrm{ha}$ of carrots

Cost of chemicals

Incineration of the crop at $\$ 150$ per tonne $\quad-\$ 2700$ Total

$-\$ 6950$

The above calculation does not include the cost of recovering the gold metal from the plant ash. However, neither does it include the potential dividend from possible energy recovery from the incineration process itself. Such an idea is not fanciful and indeed in Queensland, electricity is routinely sold to the National Grid after incineration of the bagasse residue from the sugar processing industry. We are at present experimenting with different ways of removing gold from plant material and hope soon to be able to estimate the true cost of the final process in phytomining to gold.

More detailed calculations of the economics of phytomining for gold are given in Table 2 from which it is clear that of the five root crops studied, only carrot is likely to provide an economic return for phytomining. Although the higher return would appear to be possible with use of thiosulfate as the inducing agent, it is our experience that gold extraction does not occur at lower $\mathrm{pH}$ values when this reagent is used. If it is desired to use thiosulfate for this purpose, it may be necessary to carry out the additional expense of liming. Most mine tailings have a pH well below 7.0 and it is difficult to grow plants at $\mathrm{pH}<4.0$. For the more acid tailings additional liming will be necessary even if thiocyanate is to be used.

The anticipated return of $\$ 840 /$ ha for gold recovery with thiocyanate use is over double the return for a crop of wheat in the USA at current world prices.

Environmental concerns have to be addressed if chemicals are to be added to the soil. Despite their name similarity to cyanide, thiocyanates have low toxicity. The ammonium salt has an $\mathrm{LD}_{50}$ of 500 $\mathrm{mg} / \mathrm{kg}$ for animals (4). The toxicity of thiosulfates is even lower and is about equal to that of common salt. Thiosulfates are extremely unstable, particularly at lower $\mathrm{pH}$ values and have a half life of only a few days in soils. Thiocyanates are also unstable in the environment. Their half-life in the environment has been assessed at about 6 months (5). Provided that neither chemical can be leached quickly into river systems, they are unlikely to present a serious environmental problem.

Our experiments have shown that root crops such as carrot may have potential for phytomining for gold provided that climatic and other conditions are suitable for this root crop. Further tests will of course be necessary to establish the potential of various carrot cultivars for phytomining. It will also be necessary to investigate the possibility of using tropical and subtropical roots crops such as cassawa and sweet

Table 2 Economics of Phytomining for Gold using Root Crops (tops+roots)

$\begin{array}{lcc}\text { Plant or treatment } & \text { Gold yield }(\mathbf{g} / \mathbf{h a}) * & \text { Gold value (\$US) } \\ \text { THIOCYANATE } & 779 & 7790 \\ \text { Carrot } & 162 & 1620 \\ \text { Onion } & 75 & 750 \\ \text { Red beet } & 237 & 2370 \\ \text { Salad radish } & 209 & 2090 \\ \text { Oriental radish } & & \\ \text { THIOSULFATE } & 1450 & 14500 \\ \text { Carrot } & 79 & 790 \\ \text { Onion } & 47 & 470 \\ \text { Red beet } & & \\ & & \\ \text { From final column of Table I. } & & \\ * \text { After subtraction of } \$ 6950 / \text { ha for agronomic, incineration and chemical costs. }\end{array}$


potato to extend the scope of phytomining to warmer parts of the globe where these crops are often present and where local people have experience in their cultivation. It is true that there are additional costs involved in harvesting root crops, but this is more than offset by the much higher gold yield of the belowground plant parts.

\section{ACKNOWLEDGEMENTS}

We thank the New Zealand Overseas Development Agency for a grant to support the senior author.

\section{ABOUT THE AUTHORS}

Fletcher Msuya is a visitor from Tanzania who is working for his MSc degree. Chris Anderson is just completing doctoral studies and Robert Brooks is
Emeritus Professor. All of these workers are in the Soil and Earth Sciences Group of the Institute of Natural Resources, Massey University, Palmerston North, New Zealand.

\section{REFERENCES}

1 C.W.N. Anderson, R.R. Brooks, R.B. Stewart and R. Simcock, Nature, 1998, 395, 553

2 C.W.N. Anderson, R.R. Brooks, R.B. Stewart and R. Simcock, Gold Bull., 1999, 32, 48

3 C.J. Clarke, G.S. Smith, M. Prasad and I.S. Cornforth. 'Fertiliser Recommendations for Horticultural Crops', New Zealand Ministry of Agriculture and Fisheries, Wellington, 1986

4 T.H.J. van Hoek. Thiocyanates, inorganic, Ullmann's Encyclopedia of Industrial Chemistry, 1995, A26, 759

5 C.H. Hung and S.G. Pavlostathis, Water Res., 1997, 31, 2761

\section{Continued from page 133}

\section{ABOUT THE AUTHORS}

$\mathrm{Mr}$ Gantovnik is a $\mathrm{PhD}$ student at Virginia Polytechnic Institute, Blacksburg, VA, USA. He was formerly a research associate at the Ames Laboratory of the US Department of Energy on the campus of Iowa State University. Drs Russell, Chumbley, and Field are faculty members at Iowa State University who collaborate on physical metallurgy projects. Ms Wongpreedee is a $\mathrm{PhD}$ graduate student in the Department of Materials Science and Engineering at Iowa State University.

\section{REFERENCES}

1 A.M. Russell, K. Xu, L.S. Chumbley, J.J. Parks and J.L. Harringa, Gold Bull., 1998, $31(3), 88$

2 E.E. Underwood, 'Quantitative Stereology', Addison-Wesley, Reading, MA, USA, 1970, p. 80

3 J.D. Verhoeven, L.S. Chumbley, F.C. Laabs and W.A. Spitzig, Acta Metall. Mater., 1991,39(11), 2825

4 W.A. Spitzig, Acta Metall. Mater., 1991, 39(6), 1085

5 C. Biselli and D.G. Morris, Acta Metall. Mater, 1994, 42(1), 163

6 C. Biselli and D.G. Morris, Acta Mater, 1996, 44(2), 493
7 A.M. Russell, L.S. Chumbley and Y. Tian, Advanced Engineering Materials, 2000, 2, 11 22

8 A.M. Russell, L.S. Chumbley, T.W. Ellis, F.C. Laabs, B. Norris and G.E. Donizetti, J. Mat. Sci, , 1995, 30, 4249-4262

9 J. Bevk, J.P. Harbison and J.L. Bell, J.Appl. Phys., 1976, 49, 6031-6038

10 W.A. Spitzig and P.D. Krotz, Acta Metall, 1988, 7, 1709-1715

11 J.C. Malzahn Kampe, T.H. Courtney and Y. Leng, Acta Metall, 1989, 37(7), 1735

12 T.H. Courtney and J.C. Malzahn Kampe, Acta Metall., 1989, 37(7), 1747

13 P.D. Funkenbusch and T.H. Courtney, Acta Met., 1985, 33(5), 913

14 P.D. Funkenbusch, J.K. Lee and T.H. Courtney, Met. Trans. A., 1987, 18A, 1249

15 P.D. Funkenbusch and T.H. Courtney, Scripta Met., 1989, 23, 1719

16 P.D. Funkenbusch and T.H. Courtney, Scripta Met., 1990, 24, 1175

17 P.D. Funkenbusch and T.H. Courtney, Scripta Met., 1990, 24, 1183

18 C.L. Trybus, L.S. Chumbley, W.A. Spitzig and J.D. Verhoeven, Ultramicroscopy, 1989, 30, 315

19 A.R. Pelton, F.C. Laabs, W.A. Spitzig and C.C. Cheng, Ultramicroscopy, 1987, 22, 251

20 J. Weertman and J.R. Weertman, 'Elementary Dislocation Theory', The Macmillan Co., New York, NY, 1964, p. 3 